The Catholic University of America, Columbus School of Law

CUA Law Scholarship Repository

Scholarly Articles and Other Contributions

Faculty Scholarship

1977

\title{
A Note to Decameron 6.7: The Wit of Madonna Filippa
}

Kenneth Pennington

The Catholic University of America, Columbus School of Law

Follow this and additional works at: https://scholarship.law.edu/scholar

Part of the Law Commons

\section{Recommended Citation}

Kenneth Pennington, A Note to Decameron 6.7: The Wit of Madonna Filippa, 52 SPECULUM 902 (1977).

This Article is brought to you for free and open access by the Faculty Scholarship at CUA Law Scholarship Repository. It has been accepted for inclusion in Scholarly Articles and Other Contributions by an authorized administrator of CUA Law Scholarship Repository. For more information, please contact edinger@law.edu. 


\title{
A NOTE TO DECAMERON 6.7: THE WIT OF MADONNA FILIPPA
}

\author{
By KENNETH PENNINGTON
}

Madonna Filippa's appearance before the podestà of Prato to answer her husband's charge of adultery is one of the most dramatic scenes in the Decameron, and critics have found the story troublesome to explain. No one has yet identified its source. ${ }^{1}$ Recent interpretations illustrate the difficulties which Madonna Filippa's heroism raises. One critic confesses that neither Madonna Filippa's plight nor her actions "are conceivable in a society other than the one that the narrator sets up." Others see Madonna Filippa as a dramatic figure who saved herself with boldness and with an appeal to natural law. ${ }^{3}$ Yet another explanation is that Boccaccio used this story to illustrate the efficacy of Quintilian's rules of rhetoric. ${ }^{4}$ The novella, in other words, derives its meaning either from its relationship to other tales in the Decameron, or as a conceit which demonstrates the effectiveness of classical learning.

Much of the difficulty stems from the unlikely situation which Boccaccio created. Rinaldo de' Pugliesi discovers his wife in the arms of a lover, Lazzarino de' Guazzagliotri. Medieval law allowed Rinaldo to kill the lover and his wife if he acted immediately, ${ }^{5}$ but Boccaccio tells us that Rinaldo feared the consequences of precipitate action; why Rinaldo chose caution is not explained. The next morning, though, he fearlessly obtained a summons which required Madonna Filippa to answer the charge of adultery before the podestà. Her family and relatives urged her to ignore the summons and to go into exile, but she refused. Prato had a statute which dictated that any woman who was caught in the act of adultery should be burned alive, but her admission of guilt to the podestà was required. This was a harsh law for the fourteenth century. Although the penalties for adultery were generally severe in early medieval law, by the time in which Boccaccio was writing most legal systems did not require death for an adulteress. ${ }^{6}$ Ariosto also attributed

1 A. C. Lee, The Decameron: Its Sources and Analogues (London, 1909), p. 179. V. Branca, ed., Decameron (Florence, 1965), pp. 731-5, has not noted any source for the tale.

${ }^{2}$ S. Deligiorgis, Narrative Intellection in the Decameron (Iowa City, 1975), p. 141.

3 M. Baratto, Realtà e stile nel Decameron (Vicenza, 1970), p. 403.

${ }^{4}$ C. Muscetta, Boccaccio (Bari, 1972), pp. 251, 303. Muscetta thinks that Quintilian may have been the source of the story.

${ }^{5}$ See, for example, Frederick II's Liber Augustalis 3.81.

${ }^{6}$ In secular law, the penalty for adultery was generally a monetary fine. In ecclesiastical law, the penalties could include separation and loss of part or all of the dos or donatio. See the Bolognese statutes for 1288 in Statuti di Bologna dell'anno 1288, ed. G. Fasoli and P. Sella (Città del Vaticano, 1937), p. 195, and Petrus de Monteforte's commentary to Liber Augustalis 3.81 in Constitutionum regni Siciliarum libri III, ed. A. Cervonius (Naples, 1773), p. 425. For canon law, Goffredus de Trani, Summa super titulis decretalium (Lyon, 1519), fols. 207v-208r, describes the usual penalties. In early Germanic law, death was often prescribed for an adulteress, see e.g. sections 211, 212 and 213 of Rothair's edict, trans. K. F. Drew, The Lombard Laws (Philadelphia, 1973), p. 93. 
a similar piece of draconian legislation to the Scots in Orlando Furioso, and a few Italian city-states matched l'aspra legge which had violated Rinaldo's sense of justice in Furioso. ${ }^{7}$

The podestà was sympathetic to Madonna Filippa's plight. Boccaccio tells us that he was so impressed with her beauty and charm that he all but urged her to perjure herself. He carefully instructed her that if she did not confess, then he could not condemn her to death. What she did then belongs to the world of the storyteller rather than to our own. She confessed her guilt unabashedly and presented two arguments to the the court which, surprisingly, resulted in an acquital and a change of the law.

On first glance, her actions and her words are not particularly humorous - brazen perhaps, but not witty - or rational. To the modern reader, the tale hardly seems to conform to the theme which Boccaccio set for the sixth day. She declared that the law could not apply to her because women in the past had not consented to this law, and they were not consulted when the statute was first made. Consequently, it was bad law. Laws, she said, must have the consent of those who are affected by them. She told the podestà that her argument would be familiar to him, and, indeed, it should have been. Although Madonna Filippa's situation is outlandish, her argument is a common staple of medieval thought. It was commonly expressed by the maxim, "Quod omnes tangit ab omnibus approbari debet." The maxim was often used as a description of legal consent to legislation, but its logic was never extended to women in the Middle Ages. ${ }^{8}$ The lawyers argued that legislation was required to have the consent of those affected by it, and Quod omnes tangit established itself as an important theoretical concept for many different medieval assemblies, from episcopal chapters to church councils and parliaments. By the early thirteenth century, ecclesiastical lawyers extended the maxim to laymen as well as clerics and argued that laymen should attend church councils; matters which touched lay interests needed their consent. ${ }^{9}$ In the fourteenth century, kings and princes summoned representative assemblies of their noblemen, clergy, and townsmen with

\footnotetext{
${ }^{7}$ Orlando Furioso 4.59, ed. G. Innamorati (Bologna, 1967): "L'Aspra legge di Scozia, empia e severa, vuol ch'ogni donna, e di ciascuna sorte, ch'ad uom si giunga, e non gli mogliera, s'accusata ne viene, abbia le morte." Although death was required for adultery only rarely, Professor J. A. Brundage has informed me of three city-states which had such a penalty: Cremona statutes of 1387 (c. 109, ed. 1578, p. 39), Bellona statutes of 1428 (ed. 1525, fol. 82r-v), and Bergamo (9.72, ed. 1490, fol. 143v). Prof. Brundage also noted that the nominal punishments elsewhere sometimes must have led to a crowded court calendar, for in Perugia, the statutes restricted the number of times a defendant might be charged with adultery to once per month (3.82, ed. 1523, fol. 33rb).

${ }^{8}$ For a brief discussion of the maxim and its importance in medieval thought, see $\mathrm{K}$. Pennington, "Bartolome de Las Casas and the Tradition of Medieval Law," Church History 39 (1970), 157-8. Most recently, see E. Hall, "King Henry III and the English Reception of the Roman Law Maxim 'Quod omnes tangit'," Post Scripta (Bologna, 1972), pp. 125-46.

${ }^{9}$ Especially in matters of fạith, see B. Tierney, Foundations of the Conciliar Theory (Cambridge, 1955), p. 49.
} 
writs which explained that "what touches all must be approved by all."10 But Boccaccio - and this is certainly what made the tale humorous to men (and women) of the fourteenth century - took the logic of the maxim to its absurd and improbable conclusion: even women should consent to laws.

Did Boccaccio know the maxim? I think he undoubtedly learned it when he studied canon law at Naples. The idea is such a commonplace in the writings of the lawyers that he could not have studied law for long without encountering it. ${ }^{11}$ It is not too farfetched to imagine that the ultimate legal consequences of the idea that all men should consent to legislation might have been a topic of waggish discussion in the schools, and a joke or such banter was the likely inspiration for the story. In fact, I have found one other instance of Quod omnes tangit being used in a humorous or ironic sense in William of Ockham's Dialogus. In book five, the magister declares that women should not be excluded from a general council, especially in matters of faith "quae omnes tangit." His student responds that he cannot take such an irrational argument seriously and will move on to another subject. ${ }^{12}$ Like other parts of the Dialogus, it is impossible to know whether Ockham's magister is giving the author's own opinion. Whatever the case, I think that Ockham meant to amuse his readers with the irony of this passage. ${ }^{13}$

However, Madonna Filippa was not satisfied to let the matter stand with only one argument. She next asked her husband whether she had ever denied him her body, and he admitted that she had been a compliant wife. She then retorted: "What am I to do with the surplus? Throw it to the dogs?" Far better, she continued, to bestow it on her lover than to let it spoil or go to waste. ${ }^{14}$

Madonna Filippa's notion that a woman can have surplus sexuality and

$\rightarrow$ B. Tierney, "Medieval Canon Law and Western Constitutionalism," Catholic Historical Review 52 (1966-67), 1-17.

${ }^{11}$ Branca thinks that Boccaccio may have studied canon law for as long as six years: V. Branca, Boccaccio: The Man and His Works, tr. R. Monges and D. McAuliffe (New York, 1976), pp. 31-3.

12 "Dicitur quod hoc est propter unitatem fidei virorum et mulierum, quae omnes tangit . . . non est mulier a generali concilio excludenda. Discipulus. Istam assertionem de mulieribus (quae secundum Apostolum docere non debent) tam irrationabilem aestimo, quod nolo eam amplius pertractari." Ed. M. Goldast, Monarchia s. Romani imperii (Frankfurt, 1614), 2:605. Ockham used the same argument in his Epistola ad Fratres Minores, but did not unequivocally endorse the opinion. See J. B. Morrall, "Ockham and Ecclesiology," Medieval Studies Presented to Aubrey Gwynn, S. J. (Dublin, 1961), p. 483. A. S. McGrade, The Political Thought of William of Ockham (Cambridge, 1974), p. 222, accepts Ockham's argument as a serious one.

${ }^{13}$ Ockham had a penchant for pushing arguments to extremes. He stated several times that the entire church might be heretical except for women, children, or even one solitary Christian. Perhaps here too, Ockham was using irony. The most recent discussion of these issues is G. Leff, William of Ockham: The Metamorphosis of Scholastic Discourse (Manchester, 1975), p. 639.

14 "Che voi mio marito domandiate se io ogni volta, e quante volte a lui piaceva, senza dir mai di no, io di me stessa gli concedeva intera copia o no. . . . Domando io, messer podestà, se egli ha sempre di me preso quello che gli è bisognato e piaciuto, io che doveva fare o debbo di quel che gli avanza? Debbolo io gittare ai cani? Non è egli molto meglio servirne un gentile uomo che più che sé m'ama, che lasciarlo perdere o guastare?" 
might not be satisfied by her husband has some foundation in medieval views of feminine sexuality. Following Galen, some medieval authors thought that if a woman did not have sexual intercourse, a "semen" which was produced by the uterus would spoil and corrupt her blood. Such an unsatisfied libido led to hysteria. ${ }^{15}$ Her argument also reminded her listeners of the common medieval idea that the husband was - and should be - the lord of his wife. As a consequence, Boccaccio compared a wife's unslaked passion with the food and drink which servants may take from the table after their master has been satisfied. Just a few stories earlier on the same day (6.2), Pampinea had told the tale of a servant who had taken wine to his master's friend in too large a bottle so that he could drink what would remain in the flask. This motif may have provided a connection with Madonna Filippa's argument in the seventh tale. Further, critics have not noticed that Boccaccio made his comparison more amusing with an explicit reference to Matthew 7.6: "You must not give that which is holy to the dogs" (Nolite dare sanctum canibus). The allusion to Matthew 7.6 underlined the relationship of Boccaccio's alimental and sexual-excess metaphor and gave Madonna Filippa's second argument a parodical justification; Boccaccio may have even known that "sacrum" was sometimes a euphemism for a woman's body. ${ }^{16}$ The story, then, derives its humor from Boccaccio's parody of a legal maxim and of a biblical quotation, and these two subtle allusions give substance to a tale which might otherwise appear to be a shallow piece of wit.

At the beginning of the tale, Boccaccio says that Madonna Filippa will "provide laughter and merriment to her listeners." This certainly is not a heuristic story which demonstrates the efficacy of ancient or medieval dialectic, nor do her arguments appeal to natural law. Most importantly, although Madonna Filippa has become famous as an example of Love's giving courage and bravery to a woman, Boccaccio used her only as a vehicle: the joke is the important element of the tale, not the characters. ${ }^{17}$ All of Boccaccio's critics have seen that her arguments would never have convinced the real podestà of Prato. Boccaccio never intended that they should. Perhaps he would explain the story - and much of the Decameron - by noting that a beautiful woman who amuses us should never be treated unkindly.

\section{SyRACUSE UNIVERSITY}

${ }^{15}$ V. L. Bullough, "Medieval Medical and Scientific Views of Women," Viator 4 (1973), 495-6.

${ }^{16}$ D. W. Robertson, Jr., A Preface to Chaucer: Studies in Medieval Perspectives (Princeton, 1962), p. 428.

${ }^{17}$ Madonna Filippa must make her appearance before the podestà in order for the story to have its humor, and attempts to see more than that in the tale are off the mark: e.g., A. D. Scaglione, Nature and Love in the Late Middle Ages (Berkeley and Los Angeles, 1963), pp. 37 and 168. 